\title{
Isolated Adrenocorticotropic Hormone Deficiency Secondary to Chronic Opiate Use
}

\author{
Rishi Raj ${ }^{1}$, Aasems Jacob ${ }^{2}$, Ghada Elshimy ${ }^{3}$, Jackson Smith ${ }^{4}$ \\ 1. Endocrinology, University of Kentucky, Lexington, USA 2. Hematology and Oncology, University of Kentucky, \\ Lexington, USA 3. Endocrinology, Diabetes, and Metabolism, University of Arizona College of Medicine - Phoenix, \\ Phoenix, USA 4. Endocrinology, Diabetes, and Metabolism, University of Kentucky, Lexington, USA
}

Corresponding author: Rishi Raj, rishiraj91215@gmail.com

\begin{abstract}
Although opiate use can result in various endocrine disorders, isolated adrenocorticotropic hormone (ACTH) deficiency resulting in secondary adrenal insufficiency remains uncommon. We present a case of a 54-yearold woman with a history of chronic opiate use who presented with a four-month history of worsening fatigue and syncopal episodes. Laboratory workup revealed a low ACTH with low baseline cortisol and normal levels of rest of the anterior pituitary hormones. The imaging study did not reveal any pituitary abnormality. The patient was diagnosed with opiate-induced isolated ACTH deficiency. Her symptoms improved after treatment with hydrocortisone. This case would further improve clinician's awareness towards opiate-induced endocrinopathies, including isolated ACTH deficiency, which can present with nonspecific signs and symptoms, creating a diagnostic challenge.
\end{abstract}

Categories: Endocrinology/Diabetes/Metabolism, Internal Medicine, Pain Management

Keywords: acth deficiency, secondary adrenal insufficiency, pituitary hormones, acth, pituitary disorders, opiate, chronic pain, chronic pain management

\section{Introduction}

Opiate use has become a global epidemic in recent times. Although its use has been well recognized to cause various endocrinopathies, the mechanism of opiate-induced endocrinopathies remains poorly understood [1]. Opiated-induced hypogonadism is the most common endocrinopathy, with prevalence ranging from $35 \%$ to $90 \%$ among males [2]. Suppression of the hypothalamic-pituitary-adrenal (HPA) axis can also be seen. Due to its vague symptoms and latent presentation, opiate-induced secondary adrenal insufficiency is significantly underdiagnosed. This can lead to patient presentation in adrenal crisis, which carries very high morbidity and mortality. Discontinuation of opiate use can result in possible recovery of the HPA function. Appropriate hormone replacement with steroids remains the cornerstone of management.

Received 06/29/2020 Review began 07/04/2020 Review ended 07/07/2020 Published 07/19/2020

\section{() Copyright 2020}

Raj et al. This is an open access article distributed under the terms of the Creative Commons Attribution License CC-BY 4.0., which permits unrestricted use, distribution, and reproduction in any medium, provided the original author and source are credited.

\section{Case Presentation}

A 54-year-old woman presented for evaluation of intermittent syncopal episodes for the past four months. She described syncopal episodes preceded with profuse sweating and shaking, which improved after meals. She also had fatigue, dizziness, and salt craving but denied any headache or weight loss. Her past medical history was significant chronic back pain treated with as-needed oral hydrocodone $5 \mathrm{mg}$ every six to eight hours for one year. She was not on any other medications including NSAIDs. She was previously treated with acetaminophen without control for back pain and hence was treated with opiates. She did not have a prior history of head trauma, radiation, or pituitary/brain surgery. Family history was negative for autoimmune disease. She was a current smoker (10 packs per year). On physical examination, she was normotensive 136/83 mmHg with a pulse rate of 84 beats per minute, and a temperature of 97.6 degree Fahrenheit. Orthostatic vital signs were negative. She did not have hyperpigmentation of her skin. Visual field testing was normal. Cardiovascular and neurological causes of syncope were ruled out. Adrenocorticotropic hormone (ACTH) stimulation test with $250 \mathrm{mcg}$ of intramuscular cosyntropin showed serum cortisol levels of $<2.0,7.3$, and $8.3 \mathrm{ug} / \mathrm{dL}$ at time 0,30 , and 60 minutes respectively. Baseline ACTH level was $3.4 \mathrm{pg} / \mathrm{mL}$ (reference range: $7.2-63.3 \mathrm{pg} / \mathrm{mL}$ ). The remaining laboratory workup is shown in Table 1 . She had normal plasma renin activity with normal aldosterone, sodium, and potassium level. Estradiol level was in the postmenopausal range. MRI of the pituitary with and without contrast did not show a pituitary tumor or other abnormalities. She was diagnosed with opiate-induced isolated ACTH deficiency and was treated with physiologic dose of oral hydrocortisone $10 \mathrm{mg}$ in the morning and $5 \mathrm{mg}$ at $4 \mathrm{PM}$ with significant improvement in her symptoms. She was reluctant to taper off the opioid as her pain was not controlled on other analgesics. At three months, she remained asymptomatic on the current dose of oral hydrocortisone. 


\section{Cureus}

\begin{tabular}{|c|c|c|}
\hline Laboratory test & Results & Reference ranges \\
\hline Serum sodium & $143 \mathrm{mmol} / \mathrm{L}$ & 136-145 mmol/L \\
\hline Serum potassium & $3.8 \mathrm{mmol} / \mathrm{L}$ & $3.7-4.8 \mathrm{mmol} / \mathrm{L}$ \\
\hline Serum bicarbonate & $23 \mathrm{mmol} / \mathrm{L}$ & $22-29 \mathrm{mmol} / \mathrm{L}$ \\
\hline Serum chloride & $107 \mathrm{mmol} / \mathrm{L}$ & $97-107 \mathrm{mmol} / \mathrm{L}$ \\
\hline Serum calcium & $9.7 \mathrm{mg} / \mathrm{dL}$ & $8.9-10.2 \mathrm{mg} / \mathrm{dL}$ \\
\hline Plasma aldosterone & $3.1 \mathrm{ng} / \mathrm{dL}$ & $0-30 \mathrm{ng} / \mathrm{dL}$ \\
\hline Plasma renin activity & $1.74 \mathrm{ng} / \mathrm{ml} / \mathrm{h}$ & $0.25-5.82 \mathrm{ng} / \mathrm{ml} / \mathrm{h}$ \\
\hline TSH & $0.45 \mathrm{ulU} / \mathrm{mL}$ & 0.4-4.2 ulU \\
\hline FT4 & $1.5 \mathrm{ng} / \mathrm{dL}$ & $0.8-1.8 \mathrm{ng} / \mathrm{dL}$ \\
\hline IGF-1 & $118 \mathrm{ng} / \mathrm{mL}$ & $53-287 \mathrm{ng} / \mathrm{mL}$ \\
\hline Prolactin & $5.9 \mathrm{ng} / \mathrm{mL}$ & $4.4-23.3 \mathrm{ng} / \mathrm{mL}$ \\
\hline FSH & $38.1 \mathrm{mlU} / \mathrm{ml}$ & $25.8-134.8 \mathrm{mlU} / \mathrm{mL}$ \\
\hline LH & $18.3 \mathrm{mlU} / \mathrm{mL}$ & $7.7-58.5 \mathrm{mlU} / \mathrm{mL}$ \\
\hline Estradiol & $22 \mathrm{pg} / \mathrm{mL}$ & 0-30 pg/mL (postmenopausa \\
\hline
\end{tabular}

TABLE 1: Summary of the laboratory workup.

TSH, thyroid stimulating hormone; FT4, free thyroxine; IGF-1, insulin-like growth factor-1; FSH, follicle stimulating hormone; LH, luteinizing hormone

\section{Discussion}

The first case of isolated ACTH deficiency was described in 1954 by Steinberg et al. [3]. Among the pediatric population, it is exclusively due to genetic mutations. However, in recent times, opiate use has emerged as one of the leading causes of secondary adrenal insufficiency. Nonetheless, it is believed to be significantly underdiagnosed. Besides opiate use, other conditions that can lead to isolated ACTH deficiency include autoimmune conditions, lymphocytic neurohypophysitis, and immune checkpoint inhibitors [4-8]. Despite the fact that it has been decades since the first reported case, this remains a poorly understood entity. From limited research, opioids are known to work on the hypothalamic-pituitary-adrenal (HPA) axis at three primary opioid receptors ( $\mu, \delta$, and $\mathrm{k}$ ), leading to a lack of ACTH secretory response to corticotropinreleasing hormone $(\mathrm{CRH})[9]$.

The true prevalence of opiate-induced secondary adrenal insufficiency remains unclear and currently available data are primarily from few retrospective studies and case reports [10]. Few studies have suggested that chronic use of opiates can disrupt the normal circadian rhythm of cortisol secretion as well [11].

The clinical presentation of isolated ACTH deficiency is nonspecific and can include fatigue, anorexia, weakness, hypoglycemia, and loss of consciousness [12-13]. Our patient presented with fatigue, dizziness, salt craving, and intermittent loss of consciousness, which could be from hypoglycemia after prolonged fasting. Unfortunately, our patient did not have documentation of low glucose levels and we can only assume her symptoms to be due to hypoglycemia which resolved after treatment of secondary adrenal insufficiency. Apart from vague presenting symptoms, these patients also have a latent presentation and very few patients seek timely medical attention, which can significantly delay the diagnosis. Rarely, these patients can present in adrenal crisis with hypovolemia, hyponatremia, and hypoglycemia after an acute illness [13].

Once isolated ACTH deficiency is suspected, the diagnosis can be confirmed by demonstrating selective functional loss of corticotropes, evidenced by low levels of ACTH and cortisol along with normal levels of the other five anterior pituitary hormones - thyroid stimulating hormone (TSH), follicle stimulating hormone (FSH), luteinizing hormone (LH), insulin-like growth factor 1 (IGF1), and prolactin [14-16]. Some studies have also suggested a demonstration of the failure of adrenal glands to respond to CRH along with normal secretory indices of other anterior pituitary hormones to establish the diagnosis of isolated ACTH deficiency [13]. The CRH stimulation test can further help in distinguishing between supra-pituitary and pituitary dysfunction as the underlying etiology of isolated ACTH deficiency, which in turn could be from $\mathrm{CRH}$ deficiency, $\mathrm{CRH}$ resistance, or dysfunction of pituitary corticotropes. Although a combination of CRH 
stimulation test and insulin tolerance test can be used to diagnose the underlying etiology of isolated ACTH deficiency, most patients with isolated ACTH deficiency show a pituitary defect following the CRH stimulation test, suggesting an extremely low incidence of the supra-pituitary defect [17]. Besides, insulin tolerance test (ITT) is not used nowadays due to its complications.

Nonetheless, isolated ACTH deficiency is treated similar to any case of secondary adrenal insufficiency with physiologic doses of hydrocortisone given in divided doses with recommendations to increase the doses at times of stress such as fever, infection, or other illnesses. Besides, steroids, limited studies have shown a possible role of intranasal ACTH replacement therapy in patients with isolated ACTH deficiency [18].

\section{Conclusions}

Opioid-induced isolated ACTH deficiency is an underdiagnosed condition in clinical practice, which can be attributed to under-reporting of symptoms by patients as well as poor clinician awareness. Healthcare professionals should be familiar with the adverse events associated with opiates. Furthermore, they should caution patients at the initiation of treatment, particularly if long-term treatment with opiates is desired. Additionally, patients on chronic opiates should be appropriately monitored with hormonal workup.

\section{Additional Information}

\section{Disclosures}

Human subjects: Consent was obtained by all participants in this study. Conflicts of interest: In compliance with the ICMJE uniform disclosure form, all authors declare the following: Payment/services info: All authors have declared that no financial support was received from any organization for the submitted work. Financial relationships: All authors have declared that they have no financial relationships at present or within the previous three years with any organizations that might have an interest in the submitted work. Other relationships: All authors have declared that there are no other relationships or activities that could appear to have influenced the submitted work.

\section{References}

1. Fountas A, van Uum S, Karavitaki N: Opioid-induced endocrinopathies. Lancet Diabetes Endocrinol. 2020, 8:68-80.

2. Baillargeon J, Raji MA, Urban RJ, et al.: Opioid-induced hypogonadism in the United States . Mayo Clinic Proc Innov Qual Outcomes. 2019, 19:276-284. 10.1016/j.mayocpiqo.2019.06.007

3. Steinberg A, Shechter FR, Segal HI: True pituitary Addison's disease, a pituitary unitropic deficiency; fifteen-year follow-up. J Clin Endocrinol Metab. 1954, 19:1519-1529.

4. Murakami T, Wada S, Katayama Y, et al.: Thyroid dysfunction in isolated adrenocorticotropic hormone (ACTH) deficiency: case report and literature review. Endocrine J. 1993, 19:473-478.

5. Richtsmeier AJ, Henry RA, Bloodworth JM, Ehrlich EN: Lymphoid hypophysitis with selective adrenocorticotropic hormone deficiency. Arch Intern Med. 1980, 19:1243-1245.

6. Tanaka S, Kushimoto M, Nishizawa T, et al.: Isolated ACTH deficiency during single-agent pembrolizumab for squamous cell lung carcinoma: a case report. Clin Diabetes Endocrinol. 2020, 19:6.

7. Takeno A, Yamamoto M, Morita M, et al.: Late-onset isolated adrenocorticotropic hormone deficiency caused by nivolumab: a case report. BMC Endocrine Disord. 2019, 19:10.1186/s12902-019-0335-x

8. Takebayashi K, Ujiie A, Kubo M, et al.: Isolated adrenocorticotropic hormone deficiency and severe hypercalcemia after destructive thyroiditis in a patient on nivolumab therapy with a malignant melanoma. I Clin Med Res. 2018, 19:358-362.

9. Fountas A, Chai ST, Kourkouti C, et al.: Mechanisms of endocrinology: endocrinology of opioids . Eur J Endocrinol. 2018, 179:R183-R196.

10. Donegan D, Bancos I: Opioid-induced adrenal insufficiency. Concise Rev Clin. 2018, 93:P937-P944.

11. Facchinetti F, Volpe A, Farci G, et al.: Hypothalamus-pituitary-adrenal axis of heroin addicts. Drug Alcohol Depend. 1985, 20:361-366.

12. Andrioli M, Giraldi FP, Cavagnini F: Isolated corticotrophin deficiency. Pituitary. 2006, 19:289-295.

13. Yamamoto T: Isolated ACTH deficiency: latent nature in adults. Endocrinologist. 2009, 19:108-113. 10.1097/TEN.0b013e3181a7f2a8

14. Kubo SI, Kitamura O, Orihara Y, Tsuda R, Hirose W, Nakasono I: Isolated adrenocorticotropic hormone deficiency: an autopsy case of adrenal crisis: a case report. Am J Forensic Med Pathol. 1997, 19:202-205.

15. Mori T, Murakami Y, Nishiki M, et al.: Expression of hypothalamic corticotropin-releasing hormone-like immunoreactivity in isolated ACTH deficiency: a report of an autopsied case. J Endocrinol Investig. 2003, 19:556-559.

16. Fischer JE, Stallmach T, Fanconi S: Adrenal crisis presenting as hypoglycemic coma. Intens Care Med. 2000, 19:105-108.

17. Gold PW, Kling MA, Khan I, et al.: Corticotropin releasing hormone: relevance to normal physiology and to the pathophysiology and differential diagnosis of hypercortisolism and adrenal insufficiency. Adv Biochem Psychopharmacol. 1987, 20:183-200.

18. Hiroi N, Ichijo $\mathrm{T}$, Ueshiba $\mathrm{H}$, et al.: Intranasal administration of adrenocorticotropin-(1-24) stimulates adrenocortical hormone secretion. J Clin Endocrinol Metab. 2002, 19:1750-1753. 